\title{
TINJAUAN VARIASI MELODI DAN STRUKTUR LAGU "6 VARIATIONS ON FOLIES d'ESPAGNE OP.45" KARYA MAURO GIULIANI
}

\author{
Ditya Cahya Putra
}

\author{
Program Studi Seni Musik, Jurusan Sendratasik, \\ Fakultas Bahasa Dan Seni, Universitas Negeri Surabaya \\ Email: dityacahya13@gmail.com
}

\begin{abstract}
The song "6 Variations on Folies d'Espagne Op.45" is a song composed by Mauro Giuseppe Sergio Pantaleo who was familiarly known as Mauro Giuliani. This study aims to describe the melodic variations and the structure of the song 6 Variations on Folies d'Espagne Op.45 by Mauro Giuliani. The statement of the problems in this study are: 1) How is the structure of the song "6 Variations on Folies d'Espagne Op.45" by Mauro Giuliani 2) How is the variation in the song "6 Variations on Folies d'Espagne Op.45" by Mauro Giuliani. This study is a qualitative descriptive study. The writer is interested to conduct this study about melodic variation technique due to the uniqueness found in the song 6 Variations on Folies d'Espagne Op.45 which was composed by Mauro Giuliani. The theme of this song using more variations of different rhythms. In this method, the focus of the study is the full score of "6 Variations on Folies d'Espagne Op.45" by Mauro Giuliani. The result of the analysis is the structure of the song "6 Variations on Folies d'Espagne Op.45" consisting of 3 parts with tempo Andantino, Adagio, Vivace with 3 single themes. Melodic variations that occur in the main melody are melodic variation and fake, while the variations used outside the main melody include counter melody, variation rhythmyc and fake rhythmyc.
\end{abstract}

Keywords: “6 Variations on Folies d'Espagne Op.45”, Melodic Variations, Song Structure

Abstrak: Lagu "6 Variations on Folies d'Espagne Op.45” merupakan lagu yang ditulis oleh Mauro Giuseppe Sergio Pantaleo yang akrab dikenal dengan panggilan Mauro Giuliani. Penelitian ini bertujuan untuk mendeskripsikan Variasi Melodi dan Struktur lagu 6 Variations on Folies d'Espagne Op.45 karya Mauro Giuliani. Rumusan masalah dalam penelitian ini adalah: 1) Bagaimana struktur lagu "6 Variations on Folies d'Espagne Op.45" karya Mauro Giuliani 2) Bagaimana variasi pada lagu "6 Variations On Folies d'Espagne Op.45" karya Mauro Giuliani. Jenis Penelitian ini merupakan penelitian deskriptif kualitatif. Penulis tertarik meneliti tentang teknik variasi melodi ini dikarenakan keistimewaan lagu 6 Variations On Folies d'Espagne Op.45 yang diciptakan Mauro Giuliani untuk temanya lebih banyak menggunakan variasi ritme yang berbeda-beda. Dalam metode tersebut subjek penelitiannya adalah full score "6 Variations On Folies d'Espagne Op.45" oleh Mauro Giuliani. Hasil analisis yang didapat adalah struktur lagu "6 Variations On Folies d'Espagne Op.45" terdiri dari 3 bagian dengan tempo Andantino, Adagio, Vivace dengan 3 tema. Variasi melodi yang terjadi pada melodi utama adalah melodic variation and fake dan kemudian variasi yang digunakan diluar melodi utama antara lain counter melody, variation rhytmyc and fake rhytmyc

Kata Kunci: 6 Variations on Folies d'Espagne Op.45”, Variasi Melodi, Struktur Lagu.

\section{PENDAHULUAN}

Seni adalah kemampuan seseorang atau kelompok orang untuk menciptakan berbagai impuls melalui panca indera atau juga melalui kombinasi dari beberapa unsur pada panca indera, menyentuh rasa halus manusia disekitarnya sehingga lahir penghargaan terhadap nilai-nilai keindahan impuls-impuls tadi, Dengan demikian akan terjadi apresiasi yang dapat berukuran tinggi atau rendah menurut intensitas penyentuhan hati dan jiwa manusia yang tersentuh (Selo sumarjan, Analisis kebudayaan, 2001, No.2,137) Seni musik adalah pengungkapan rasa keindahan setiap seorang manusia yang diwujudkan di dalam nada atau bunyi yang pada akhirnya menghasilkan ritme dan harmoni.

Musik adalah cabang seni yang membahas dan menetapkan berbagai suara ke dalam pola-pola yang dapat dimengerti dan dipahami manusia (banoe,2003:288). Musik adalah suatu produk dari akal manusia (bersamaan dengan hasil seni yang lainnya seperti misalnya sastra) musik bukanlah suatu kenyataan objektif seperti harmoni bintang yang seakan-akan "mendikte" manusia untuk menciptakan/mendengarkan musik menurut suatu skema (Prier,2009:123). Musik diartikan sebagai cabang seni yang menggunakan media bunyi (untuk musik instrumental) dan suara 
manusia (untuk vocal). Musik juga memiliki arti yang ditulis di Kamus Besar Bahasa Indonesia (2002:766) yaitu nada atau suara yang disusun sedemikian rupa sehingga mengandung irama, lagu dan keharmonisan terutama yang menggunakan alat-alat yang dapat menghasilkan bunyi.dari berbagai penjelasan teori tentang pengertian musik tersebut dapat dijabarkan bahwa musik merupakan bentuk seni dari manusia dan berkembang melalui suara yang berupa ritme kemudian nada-nada disusun menjadi sebuah melodi yang berhubungan dengan harmoni selaras. Musik adalah ilmu pengetahuan dan seni tentang kombinasi ritmik dan nada-nada baik vokal maupun instrumental yang meliputi melodi dan harmonis yang diungkapkan sebagai ekspresi dari segala sesuatu yang ingin diungkapkan sebagai aspek emosional dan pada akhirnya musik sebagai ilustrasi kehidupan manusia yang setiap jamannya perkembangan budaya disetiap masing-masing jamannya. Musik menyusun nada atau suara dalam urutan keseimbangan hubungan temporal yang menghasilkan komposisi musik yang mempunyai kesatuan dan kesinambungan dan keindahan suara agar mudah dapat didengar oleh penikmat musik. Musik merupakan hasil dari suatu karya dalam bentuk perasaan dan pikiran penciptannya secara struktur yang mencangkup meliputi melodi, harmoni dan ritme yang disusun menjadi suatu irama yang terdiri dari musik instrumental atau vokal.

Musik klasik adalah suatu karya seni yang merupakan daya ekspresi para komponis dalam periode tertentu dan menciptakan sejarah sehingga dapat bertahan terus. Kemudian klasik diartikan sebuah karya yang bernilai seni yang tiggi yang mengandung keindahan dan tak akan hilang sepanjang masa. Bisa disimpulkan adalah suatu komposisi musik yang terdapat dari periode tertentu berstuktur yang mencerminkan gaya para komponisnya yang dapay menghasilkan suatu karya seni yang mengandung keindahan yang bertahan sepanjang masa. Dalam musik klasik merupakan istilah luas yang biasanya mengarah pada musik yang dibuat atau berakar dari tradisi kesenian barat dan mencangkup dari sekitar abad ke-9 hinggah abad ke 21. Musik klasik dibedakan dari bentuk musik non klasik atau populer terutama dari segi notasi musiknya yang sudah digunakan sejak sekitar abad ke-16. Notasi musik barat digunakan oleh setiap komponis untuk memberikan petunjuk kepada pembawa musik mengenai tinggi nada, kecepatan, ritme individual dan pembawaan suatu karya musik.

Dalam karya 6 variations karya Mauro Giuliani mengembangkan variasi melodi yang sangat bervariasi mulai dari sebuah pola ritme yang didalamnya terdapat lompatan-lompatan nada yang naik dan turun. Dalam sebuah 6 variations ada beberapa tema dan beberapa bagian, oleh karena itu dibutuhkan beberapa variasi melodi untuk menghidupkan suasana dalam setiap bagian tanpa menghilangkan tema melodi awalnya. Pentingnya variasi melodi dalam suatu karya 6 variations sangatlah penting, agar tidak terjebak dalam satu tema melodi yang tidak dikembangkan.

Perbedaan musik modern dengan klasik yaitu musik modern adalah musik yang mendapatkan atau sudah mendapatkan sentuhansentuhan teknologi baik dari segi instrumen maupun penyajian kemudian terdapat banyak variasi dari segi pola ritme atau harmoni yang sudah modern dan luas ketika dimainkan karya musik tersebut karena nada-nada nya banyak terdapat perbedaan dari musik klasik pada umumnya.

Karakter gaya klasik pada umumnya dilihat dari hasil karya komponisnya yang mencerminkan atau menggambarkan suatu nuansa yang berbeda dari sebelumnya dari segi ritme, harmoni, dan tekstur bentuk melodinya sehingga dapat menciptakan karakter-karakter dari masa ke masa sehingga pada setiap zaman terlahir jenis gaya klasik sehingga menjadi contoh pada saat ini.

Karakter gaya klasik dapat dilihat dari hasil karya komponisnya yang memberikan nuansa yang berbagai variasi yang berbeda dari sebelumnya pada musik zaman baroque yang terlihat dari segi ritme, tekstur dan melodinya. Karakter tiap komponis beraneka ragam dan menghasilkan nada-nada yang berbagai nuansa dalam komposisi di setiap zaman nya dikarenakan banyak faktor yang dapat mempengaruhi gaya atau ciri khas dalam menciptakan karya yang dihasilkan oleh komponisnya sehingga variasi-variasi pun muncul tiba-tiba pada zaman era tersebut

Melodi gaya klasik antaranya adalah nada penuh dan mudah untuk diingat sehingga melodi 
gaya klasik sering sekali seimbang dan simetris karen dibuat dua frase dan satu kalimat musik kemudian frase kedua dimulai dari hamper sama dengan frase pertama dan pada akhir frase yang menentukannya kemudian beberapa melodi dapat dibedakan antara gaya klasik dan baroque kemudian gaya klasik mudah dinyanyikan karena intervalnya nadanya mudah untuk dinyanyikan sedangkan kalau gaya baroque terdapat banyak kontras didalamnya sehingga sulit dan rumit sering kehilangan simetrisnya dan sulit untuk dinyanyikan.

Tema adalah lagu pokok yang menjadi landasan pengembangan lagu, serangkaian melodi atau kalimat lagu yang merupakan elemen utama dalam kontruksi sebuah komposisi, melodi pokok yang polanya selalu diulang-ulang dan dapat diuraikan dalam berbagai variasi. Istilah tema dalam komposisi musik adalah materi musikal yang menjadi dasar sebagian atau keseluruhan karya musik, dapat dipahami sebagai suatu ekspresi musik yang lengkap. Tema memberikan identitas pada sebuah karya musik bahkan apabila sebagaimana dalam komposisi tema dan variasi karya musik tersebut orisinil sekalipun.

Variasi di dalam pengertian musik adalah suatu proses yang didalamnya terdapat unsur-unsur yang lengkap seperti frase, kalimat, motif dan paragraf sebagai pokok kalimat ke pengulangan, perluasanatau pergantian secara panjang. Variasi dapat berarti perubahan dari tema pokok atau tema aslinya jenis variasi dalam musik terdapat pada tiga unsur pokok yaitu melodi, irama, dan harmoni namun selama proses penggarapan komposisi dapat memadukan ketiganya secara menyeluruh sehingga selain variasi melodi, harmoni dan irama terdapat juga variasi bebas, pholiphone dan sebagainya. Variasi melodi yang berarti mengulang kembali sebuah melodi utama dengan mempertahankan beberapa unsur tertentu dan menambahkan atau mengganti unsur yang lain, kawakami menjabarkan yaitu Variasi Melodi suatu melodi yang memiliki rasa dan karakter sendiri tetapi dapat diubah kedalam bentuk yang berbeda dengan mempertahankan unsur aslinya.

Mauro Giuseppe Sergio Pantaleo merupakan yang akrab dikenal dengan Mauro
Giuliani salah satu komponis yang berada pada abad ke 19 awal merupakan seorang gitaris Itali, pemain cello, penyanyi dan komposer di italia yang lahir pada tanggal 27 juli 1781 di negara Italia wilayah Bisceglie kemudian sekolah di wilayah Barletta lalu Giuliani dianggap sebagai salah stau virtuos gitar terkemuka, ditahun-tahun awal hidupnya Giuliani intstrumen yang pertama ia pelajari adalah Cello yang tidak pernah ia tinggalkan setelah mempelajari Cello Giuliani mencoba juga mempelajari biola kemudian di suatu hari Giuliani mulai mengabdikan dirinya untuk bermain gitar secara terus menerus dan akhirnya ia menjadi salah satu pemain gitar yang sangat terampil dalam waktu singkat nama-nama gurunya tidak diketahui dan tidak bisa memastikan pergerakannya yang tepat di itali.

Sebagai komposer gitar Giuliani sangat menyukai tema dan variasi bentuk yang sangat populer di Wina lalu Giuliani memiliki kemampuan yang luar biasa untuk menyatukan sebuah melodi menjadi sebuah bagian dengan efek musik sambil tetap setia idiom instrumen. Salah satu contoh kemampuan ini dapat di temukan dalam variasi pada tema " 6 variations on folies d'Espagne op.45". Prestasi harpsichord Giuliani sebagai komposer sangat banyak terdiri dari 150 komposisi Giuliani untuk gitar dengan nomern opus merupakan inti dari perbendaharaan gitar abad ke-19. Ia mengubah lagu-lagunya yang sangat menantang untuk gitar solo dan untuk juga orkestra dan duo gitar-violin dan gitar-flute. Sampai saat ini konser dan karya solo Giuliani masih dilakukan oleh para profesional dan masih menunjukan para gitaris untuk memainkan karya tersebut Giuliani sebagai komposer gitar klasik. Ekspresi dan nada suara Giuliani dalam bermain gitar sangat mencengangkan, dan seorang kritikus yang kompeten mengatakan dia: "dia menyuarakan adagiosnya sampai tingkat yang mustahil untuk dibayangkan oleh mereka yang tidak pernah mendengarnya melodi dalam gerakan lambat tidak dapat terhindari staccato dari piano yang membutuhkan keharmonisan harmoni.

Alasan peneliti memilih meneliti struktur dan variasi melodi pada struktur lagu 6 variations on folies d'Espagne op.45 karya Mauro Giuliani yaitu didalam perkembangan pembelajaran di kampus kurang wawasan dalam bentuk penelitian ilmiah terutama di variasi melodi, struktur musik pada 
pembelajaran mayor. Karena banyak mahasiswa yang beranggapan bahwa bermain saja sudah cukup tetapi dalam suatu pembelajaran sangatlah penting mengetahui tentang teori bentuk struktur bagian variasi melodi yang akan menunjang keefektifan dalam kuliah mayor. Untuk itu penelitian akan melakukan studi analisis musik dalam bentuk skripsi yang berjudul "Tinjauan variasi melodi dan struktur lagu 6 variations on folies d'Espagne op.45 karya Mauro Giuliani”'

\section{METODE}

Penelitian ini menggunakan pendekatan penelitian kualitatif deskriptif karena variable penelitian merupakan objek yang tidak perlu menggunakan pengukuran dan proses statistik. Menurut Moeloeng (2001: 6), data penelitian kualitatif yang dikumpulkan adalah data yang berupa kata-kata, gambar, dan bukan merupakan angka-angka. Penelitian ini bertujuan untuk mendeskripsikan variasi melodi dan struktur lagu 6 Variations on folies d'Espagne Op.45 Karya Mauro Giuliani. Data yang dianalisis adalah partitur lagu 6 Variations on folies d'Espagne Op.45 Karya Mauro Giuliani.

Dalam menganalisis struktur lagu dan variasi melodi, saya menggunakan berbagai cara diantaranya pendekatan penelitian yang digunakan adalah metode penelitian kualitatif, melakukan wawancara dengan ahli dalam bidangnya. Dalam metode tersebut subjek penelitiannya adalah full score " 6 Variations on folies d'Espagne Op.45" oleh Mauro Giuliani.

\section{HASIL DAN PEMBAHASAN}

\section{Struktur Lagu}

\section{$\underline{\text { Bagian }} \underline{\text { Andantino }}$}

Berada pada birama 1-80 terdapat beberapa bagian yaitu terdiri dari tema, variasi I, variasi II, variasi II, variasi IV yang dimulai dengan menggunakan tangga nada 1 Flat (F major) dengan sukat 3/4.

\section{A. Tema 1 Pembuka (introduce)}

Berada pada birama 1-16 terdapat 1 periode dengan frase tanya dan frase jawab. Frase tanya berada pada birama 1-8 dimulai dengan nada dan bass pada nada $\mathrm{D}$ dan dimainkan dengan dinamika mezzoforte Diawali dengan posisi 2 bass D open pada senar 4 untuk memudahkan permainan posisi pada nada bass. Frase jawab berada pada birama 9-16 dimainkan dengan teknik yang sama dan dimulai dari nada D dan diakhiri dengan nada bass $\mathrm{D}$.

\section{B. Variasi I}

Berada pada birama 17-32 terdapat I periode dengan frase tanya dan frase jawab. Pada variasi I terdapat struktur yang sama karena variasi I hanya mengambil variasi melodi dari tema 1 bagian introduce.

Frase tanya berada pada birama 17-24 dimulai dengan nada dan bass pada nada $\mathrm{D}$ dan dimainkan dengan dinamika mezzoforte. Frase jawab berada pada birama 25-32 dimainkan dengan teknik yang sama dan dimulai dari nada $\mathrm{D}$ dan diakhiri dengan nada bass D.

\section{Variasi II}

Berada pada birama 33-48 terdapat 1 periode dengan frase tanya dan frase jawab. Pada variasi II terdapat struktur yang sama karena variasi II merupakan pengembangan melodi dan teknik dari variasi I.

Frase tanya berada pada birama 33-40 dimainkan dengan dinamika mezzoforte dan posisi bass open pada nada D. Melodi merupakan pengembangan teknik dari variasi I yang awalnya menggunakan not $1 / 8$ (quaver) menjadi not $1 / 16$ (semi quaver) dan dimainkan dari melodi pada nada A dengan teknik legato pada posisi 1. Frase jawab berada pada birama 41-48 dimainkan dengan dinamika forte bertujuan untuk menciptakan interpretasi berbeda karena frase jawab hanya pengulangan dari frase tanya dan berbeda pada nada akhir.

\section{Variasi III}

Berada pada birama 49-64 terdapat 1 periode dengan frase tanya dan frase jawab. Melodi merupakan pengembangan dari not 1/16 (semi quaver) menjadi not triplet dan dimainkan menggunakan teknik arpegio dengan chord D minor pada posisi 5. 
Frase tanya berada pada birama 49-56 diawali dengan dinamika mezzoforte dimainkan menggunakan teknik arpegio pada chord D minor diawali dengan posisi jari kanan $\mathrm{a}, \mathrm{m}, \mathrm{i}, \mathrm{p}, \mathrm{i}, \mathrm{m}, \mathrm{a}$ (simbol jari kanan permainan gitar) dan diakhiri dengan chord A major sebagai chord tanya.

Frase jawab berada pada birama 57-64 dimainkan dengan teknik yang sama yaitu dengan teknik arpegio pada chord $\mathrm{D}$ minor dan diakhiri dengan chord D minor sebagai chord penutup pada variasi III.

\section{E. Variasi IV}

Berada pada birama 65-80 terdapat 1 periode dengan frase tanya dan frase jawab. Variasi IV merupakan pengembangan not triplet menjadi 1/16 (semiquaver).

Frase tanya berada pada birama 65-72 dimainkan dengan melodi oktaf dan dimulai dari nada D. Terdapat dinamika cresscendo pada birama 66 untuk memperjelas melodi chromatic untuk menuju chord D minor pada birama selanjutnya.

Frase jawab berada pada birama 73-80 dimainkan dengan teknik yang sama dengan melodi oktaf yang dimulai dari nada $\mathrm{D}$ dan diakhiri dengan nada $\mathrm{D}$ juga.

\section{Bagian II Un Poco Piu Adagio}

Berada pada birama 81-111 dimainkan dengan tangga nada D major. Pada bagian II tempo adagio berbeda dengan bagian I yang sebelumnya terdapat 1 periode dengan frase tanya dan frase jawab pada variasi tempo adagio terdapat 2 tema yang dimainkan dengan teknik yang berbeda yaitu pada pengembangan permainan bass.

\section{A. Tema I variasi $\mathrm{V}$}

Tema I variasi $\mathrm{V}$ berada pada birama 81-95 dimainkan menggunakan tangga nada $\mathrm{D}$ major diawali dengan dinamika mezzoforte dengan variasi yang awalnya dimainkan pada melodi namun pada tema I variasi $\mathrm{V}$ variasi melodinya berada pada permainan bass. Variasi melodi ditunjukan pada birama 81 nada bass melodi dimainkan dengan not 1/8 (quaver) menjadi bass melodi dengan not 1/16 (semiquaver) pada birama 89 dan 91.

\section{B. Tema II variasi $\mathrm{V}$}

Tema II variasi $\mathrm{V}$ berada pada birama 96-111 dimulai dengan pengembangan nada bass pada chord D major dengan not 1/8 (quaver) pada awal tema dan dilanjutkan chord $\mathrm{G}$ on $\mathrm{D}$ yang merupakan pengembangan nada $\mathrm{D}$ pada chord $\mathrm{G}$. Terdapat dinamika sforzando dan cresscendo pada birama 97 dan terdapat ornamen acciaccatura yang bertujuan untuk menekan melodi karena pada birama ini suara bass terdengar lebih dominan.

Tema II berakhir pada birama 111 kemudian dilanjutkan dengan dua birama akhir yaitu eksposisi pada birama 112 dan 113 yang merupakan suatu transisi dari variasi $\mathrm{V}$ menuju ke bagian III yang dimainkan dengan tempo Vivace.

\section{Bagian III Vivace}

Berada pada birama 112-167 dimainkan dengan tempo vivace dengan peralihan tangga nada yang sebelumnya pada bagian II menggunakan tangga nada $\mathrm{D}$ major pada bagian III ini kembali ke tangga nada F major dengan awalan chord D minor. Dalam bagian ini terdapat beberapa bagian antara lain eksposisi, tema 1, tema 2 dan diakhiri dengan kalimat penutup (epilog) pada chord D major.

Pada bagian III ini terdapat peralihan tangga nada dari tema 1 ke tema 2 yang semula menggunakan tangga nada $\mathrm{F}$ major pada tema 1, pada tema 2 menggunakan tangga nada D major. Terdapat juga ornamen acciaccatura pada tema 1 dan dimainkan dengan teknik staccato dalam tempo vivace untuk memperjelas gaya permainan gitar klasik pada bagian ini.

\section{A. Eksposisi}

Berada pada birama 112-113 pada awal bagian III. Eksposisi ini menjadi bagian peralihan dari bagian II ke bagian III dan dimainkan dengan dinamika ff (fortisimo) ke $p$ (piano). Bagian eksposisi menjadi salah satu bagian yang biasa terdapat pada komposisi musik bergaya klasik yang berperan untuk 
menjadi birama penyambung dari tema $1 \mathrm{ke}$ tema berikutnya.

\section{B. Tema I variasi VI}

Berada pada birama 114-145 dimainkan dengan awal permainan menggunakan dinamika $p$ (piano). Pada tema 1 banyak ornamen dan dinamika yang bertujuan untuk memberi ruang interpretasi bagi pemain.

Tema 1 dimainkan dengan tempo vivace dan teknik staccato pada bass maupun melodi untuk memperjelas permainan gaya klasik. Variasi melodi pada bagian ini hanya mengambil tema awal bagian introduce yang di variasi dengan penambahan nada ke 3 (F) dan 5 (A) yang bertujuan untuk membentuk variasi melodi dalam bentuk chord.

\section{Tema II variasi VI}

Berada pada birama 146-161 dan terdapat peralihan tangga nada yang semula pada tema 1 menggunakan tangga nada $F$ major pada tema 2 tangga nada berubah ke $\mathrm{D}$ major.

Tema 2 adalah pengembangan variasi melodi dari bagian II pada birama 81 yang semula melodi dimainkan oleh bass dengan not $1 / 8$ (quaver) pada temai ini variasi dimainkan oleh melodi asli dengan not 1/8 (quaver) juga dengan tangga nada $\mathrm{D}$ major.

Tema 2 di akhiri dengan melodi not 1/16 (semi quaver) yang di tunjukan pada birama 161 untuk mengakhiri tema 2 dan unruk membuka kalimat penutup (epilog) sebelum berakhirnya bagian III.

\section{Epilog}

Epilog berada pada birama 162-167 dimainkan dengan melodi pada bass dan dilanjutkan dengan melodi oktaf pada bass dan melodi pada birama 163. Bagian ini di mainkan dengan dinamika $f$ (forte) ke $f f$ (fortisimo) dan diakhiri chord D major dengan aksen pada chord D major sebagai tanda penutup dari variasi bagian III.

Variasi Melodi Pada 6 variations on folies d'Espagne Op.45 Karya Mauro Giuliani
Pada pembahasan variasi melodi ini, saya akan menguraikan berbagai variasi melodi yang terdapat pada 6 variations on folies d'Espagne Op.45 karya Mauro Giuliani. Untuk memperjelas, penulis mengurutkan jenis-jenis variasi yang dipergunakan sebagai berikut.

\section{Melodic variation and fake}

Melodic variation and fake yaitu dengan menyisipkan nada chord selain nada dari melodi asli, melodi asli dapat dirubah. Nada tunggal atau arpeggio dapat digunakan dalam kasus ini (Kawakami, 1975:23)

Variasi melodi Melodic Variation and fake 1 yang pertama berada pada birama 7 yang di variasi pada birama 15. Bisa diliat pada gambar diatas garis berwarna merah adalah melodi asli dengan nada bass $\mathrm{Bb}, \mathrm{D}$, G\# dan melodi dengan nada D, F, E, D dan kemudian garis berwarna hijau adalah variasinya. Melodi dimainkan dan divariasi pada nada $\mathrm{D}, \mathrm{F}, \mathrm{E}, \mathrm{G}, \mathrm{C} \#$,E dan bass $\mathrm{Bb}$, $\mathrm{G}$, A dengan variasi melodi menggunakan not 1/8 (quaver). Variasi tersebut berada pada birama akhir pada frase tanya dan divariasi pada tempat yang sama yaitu akhir frase sebelum kalimat jawab.
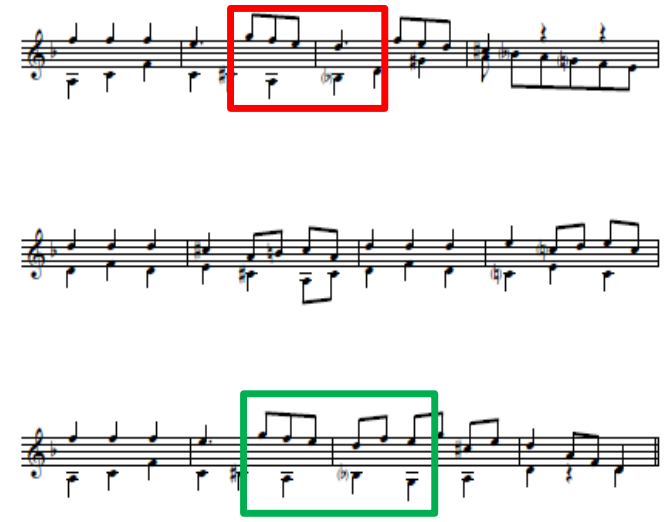

Gambar 1 Melodic variation and fake

\section{Variation Rhytmyc and Fake Rhytmyc}

Variation Rhytmyc and fake Rhytmyc merupakan perubahan melodi dengan memindahkan posisi irama tanpa mengganggu garis melodi asli. Variation Rhytmyc and fake Rhytmyc dilakukan dengan menggunakan syncopation, division and unification, sehingga 
memberikan mobilitas untuk ekspresi musik (Kawakami1975:20)

Variation Rhytmyc and fake Rhytmy 1 berada pada birama 1-8 yang di variasi pada birama 49-56. Bisa diliat pada gambar diatas garis berwarna merah adalah melodi asli dan garis berwarna hijau adalah variasinya. Pada Variation Rhytmyc and fake Rhytmyc bagian ini melodi divariasi dengan not triplet yang sebelumnya melodi hanya pada nada D dengan not 1/4(crotchet) dimainkan dengan teknik arpegio dengan tangga nada yang sama hanya saja pada bagian ini variasinya dimainkan pada teknik yang berbeda dengan not yang berbeda pula.
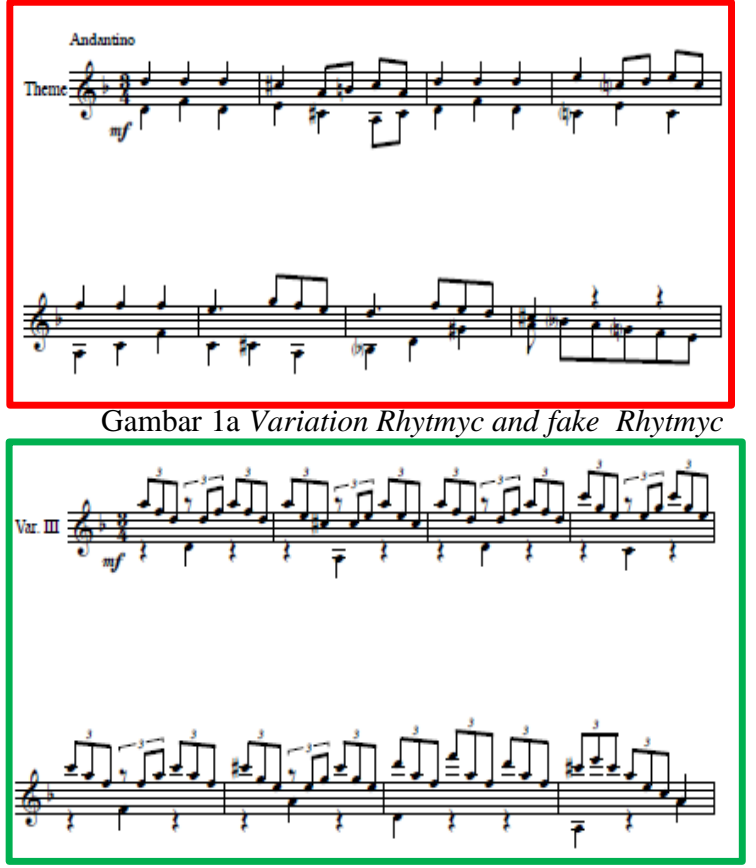

Gambar 1b Variation Rhytmyc and fake Rhytmyc

\section{Counter Melody}

Counter melody mendukung melodi dan memainkan peran penting dalam mengaransemen, dan dapat digunakan dalam berbagai cara. Fungsi utamanya adalah untuk memperkuat perasaan harmoni dengan menggunakan garis melodi kedua tetapi juga dapat digunakan untuk memberikan sentuhan aransemen individualitas melalui penyisipan frase efektif (Kawakami1975:46)

Counter melody 1 berada pada birama 21 yang di variasi pada birama 25. Bisa dilihat pada gambar diatas garis berwarna merah adalah melodi asli dan garis berwarna hijau adalah variasinya. Pada bagian ini counter melody ditunjukan pada garis melodi ke 2 yang bertujuan untuk memberikan perbedaan frase pada awal frase jawab pada variasi 1 . Bagian ini counter melody juga terdapat pada bagian bass nya yang awalnya nada bass pada nada D yang kemudian berubah menjadi nada F. Bagian ini masih pada bagian variasi I dan masih dengan tangga nada yang sama yaitu $\mathrm{F}$ dengan awalan chord $\mathrm{D}$ minor hanya saja pada 25 dimainkan dengan menggunakan dinamika $m f$ (mezzoforte).

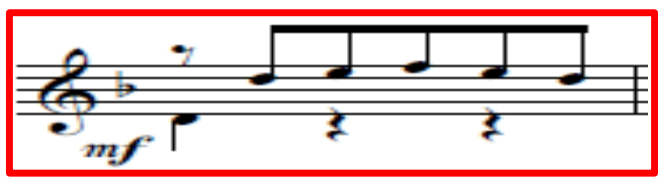

Gambar 1a Counter melody

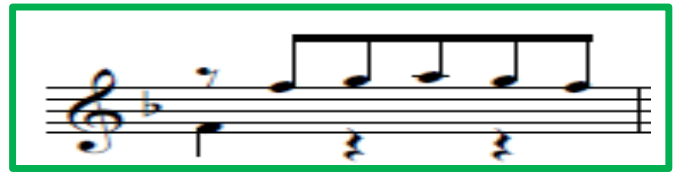

Gambar 1b Counter melody

\section{PENUTUP}

Berdasarkan hasil analisis yang telah dilakukan di lagu 6 variations on folies d'Espagne op.45 karya Mauro Giuliani ini terdiri dari 3 bagian dengan tempo Andantino, Adagio, Vivace. Dengan 3 tema dalam bagian 1 yaitu : tema 1 terdiri dari variasi I, variasi II, variasi III dan variasi IV menggunakan tempo andantino dengan sukat $3 / 4$ dimulai dengan tangga nada $1 \mathrm{~b}$ (mol) pada awal birama, kemudian bagian II yaitu : terdiri dari tema I variasi $\mathrm{V}$, tema II variasi $\mathrm{V}$ menggunakan tempo adagio terjadi perubahan tangga nada menjadi 2\# (kres), bagian III yaitu : tema I variasi VI, tema II variasi VI menggunakan tempo vivace terjadi perubahan pengulangan tangga nada menjadi $1 \mathrm{~b}$ (mol) .

6 variations on folies d'Espagne op ini terdapat 3 jenis variasi melodi seperti yang telah dijabarkan di bab iv sebelumnya. Variasi melodi tersebut ialah melodic variation and fake sebanyak 5 variasi, variation rhytmyc and fake 
Ditya Cahya Putra

TINJAUAN VARIASI MELODI DAN STRUKTUR LAGU “6 VARIATIONS ON FOLIES d'ESPAGNE OP.45" KARYA MAURO GIULIANI

rhytmyc sebanyak 7 variasi dan counter melodi sebanyak 5 variasi.

\section{DAFTAR PUSTAKA}

Moleong, L. J. (2006). Metode penelitian kualitatif edisi revisi. Bandung: Remaja Rosdakarya

Banoe, P. (2003). Kamus musik. Kanisius.

Banoe, P. (2003). Pengantar Ilmu Harmoni. Salatiga: Kanisius.

Dieter, M. (1986). Ilmu Melodi. Yogyakarta: Pusat Musik Liturgi.

Prier, K. E., \& Mack, D. (1991). Sejarah musik (Vol. 4). Pusat Musik Liturgi.

Prier, E. Karl. (1993) Sejarah Musik Jilid 2. Yogyakarta: Pusat Musik Liturgi.

Edmund Prier, K. (1993). Sejarah Musik Jilid 1 dan 2. Yogyakarta: Pusat Musik Liturgi.

Prier, K. E. (2011). Kamus Musik. Yogyakarta: Pusat Musik Liturgi.

Poerwadarminta, W. J. S. (1954). Kamus umum bahasa Indonesia. Perpustakaan Perguruan Kementerian PP dan K.
Arisasangka, I. K. (2004). Kamus skala melodi. BIP.

Kawakami, G. (1975). Aranging Populer Musik: A Protical Guide, Tokyo.

Sukohardi, A. (1978). Teori Musik Umum. Yogyakarta: Pusat Musik Liturgi.

Sugiyono, S. (2007). Metode Penelitian Kualitatif Kuantitatif dan R \& D. Bandung Alf.

Yuda Purwita Putra, A. N. G. G. E. R., \& Sarjoko, M. (2018). Tinjauan Variasi Melodi Pada Karya Musik "Kidung Dharma Samudera". Solah, 8(1).

Jatnika, N. (2017). Variasi Melodi "Passacaglia In G Minor" Karya Heinrich Ignaz Franz Biber (Doctoral Dissertation, Universitas Pendidikan Indonesia).

Astra, R. D. (2015). Analisis Bentuk Dan Struktur Lagu Fantasia On Themes From La Traviata Karya Francisco Tarrega. Skripsi. Yogyakarta: Pendidikan Seni Musik, Universitas Negeri Yogyakarta.

Jatnika, N. (2017). Variasi Melodi "Passacaglia In G Minor" Karya Heinrich Ignaz Franz Biber (Doctoral dissertation, Universitas Pendidikan Indonesia). 